\title{
Effect of weather variables on whitefly (Bemisia tabaci Gennadius) population in development of potato apical leaf curl virus disease
}

\author{
MANOJ KUMAR and ANIL GUPTA \\ Department of Plant Pathology, CCS Haryana Agricultural University, Hisar-125004, India \\ Corresponding author Email: manojbuswal@gmail.com
}

\begin{abstract}
Potato apical leaf curl virus disease (PALCVD) is an important disease in early sown potato crop transmitted by whitefly (Bemisia tabaci). The studies pertaining to impact of weather variables on population of $B$. tabaci and PALCV disease incidence on seven potato cultivars (Kufri Pushkar, Kufri Bahar, Kufri Pukhraj, Kufri Badshah, Kufri Khyati, Kufri Surya and Kufri Sadabahar) were conducted during 2012-13 and 2013-14. Results showed that the mean B. tabaci population was highest in the last week of October which varied from 24 to 85 white flies per plant. Thereafter, the population of $B$. tabaci decreased gradually with the fall in both maximum and minimum temperatures. Kufri Bahar variety had least $B$. tabaci population on all dates of observation. It was found that $B$. tabaci population (vector) was directly proportional to PALCVD. The pooled data showed that maximum temperature, minimum temperature, evening relative humidity and wind speed were the important contributing weather variables which could predict the vector populations by 57 per cent.
\end{abstract}

Keywords: Weather parameters, disease incidence, PALCVD, potato, whitefly

India is the third largest producer of potato (Solanum tuberosum L.) in the world during 2012-13. Potato crop occupied 19.99 lakh hectares with a production of 45.24 lakh tonnes tubers (Anonymous, 2013). Many factors play important role in deciding the productivity and quality of potato tubers, and disease is one of them. In Haryana state, severe yield losses due to potato apical leaf curl virus disease (PALCVD) have been reported in potato and infection due to this disease was up to 100 per cent in susceptible varieties of potato (Lakra, 2002). Potato plants infected with PALCVD showed cholorotic blotching, crinkling, mosaic, apical leaf curling and stunting (Garg et $a l ., 2001)$. The very high population of $B$. tabaci during October and November, led to high apical leaf curl incidence in potato crop (Lakra, 2010). The temperature in the range of $26-32^{\circ} \mathrm{C}$ and relative humidity of 60-70 per cent are optimal for whitefly development (Traboulsi, 1995). The positive correlation of whitefly with temperature and negative correlation with humidity in potato crop (Bhatnagar, 2007). The whitefly population was negatively correlated with rainfall (Bashir et al., 2001) but the information on their role in this disease development in potato is scanty. Therefore, studies were carried out keeping in view the importance of the weather variables and population of $B$. tabaci in development of the PALCVD in potato.

\section{MATERIALS AND METHODS}

The present investigation on the effect of weather variables on B. tabaci population and in development of PALCVD in potato was carried out in the field by planting the crop during two seasons. Seven potato varieties (Kufri Pushkar, Kufri Bahar, Kufri Pukhraj, Kufri Badshah, Kufri Khyati, Kufri Surya, and Kufri Sadabahar) were planted in split-plot design in $1^{\text {st }}$ week of October in 2012 and 2013. The plots were not given any protective spray and disease was allowed to occur on the plants. The B. tabaci population was recorded by counting it at weekly interval on ten tagged randomly selected plants by observing ten compound leaves selected from different positions, i.e., bottom, middle and top of the plant in each replication. The observations were taken early morning hours on all seven varieties and the mean value of $B$. tabaci population was calculated on all potato varieties on per plant basis. The per cent incidence on apical leaf curl virus disease was observed by counting the number of plants showing apical leaf curl symptoms along with the total number of plants in each plot as per formulae of Mckinney (1923). Whereas, the weekly data on weather variables viz., maximum temperature (Tmax), minimum temperature (Tmin), morning relative humidity (RHm), evening relative humidity (RHe), wind speed (WS), sun shine hour (SS), and rainfall (Rain) was obtained from 


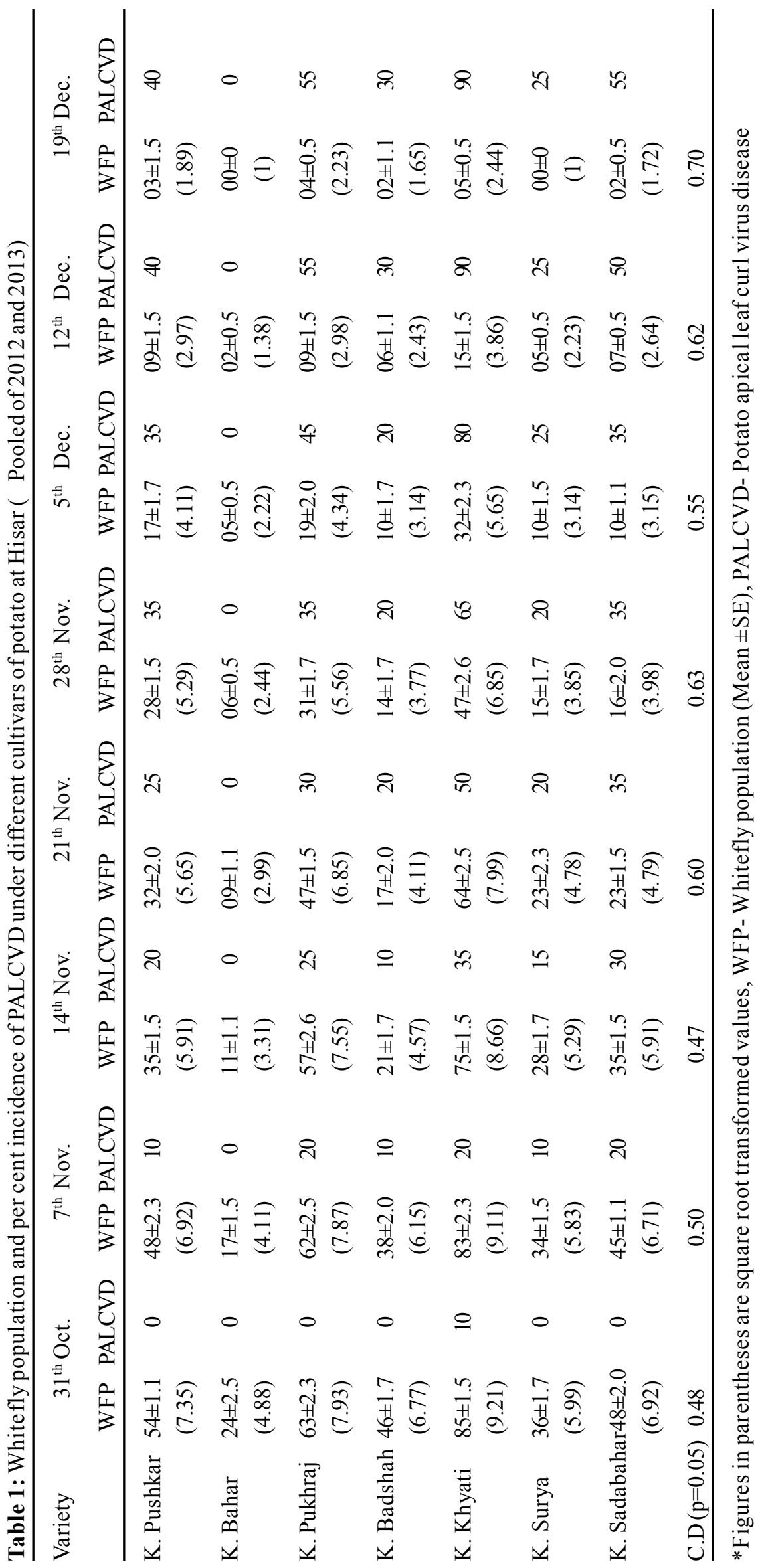


Table 2: Correlations coefficient between whitefly population with weather parameters (pooled for 2012 and 2013).

\begin{tabular}{lcccccc}
\hline Variety & Tmax & Tmin & RHm & RHe & WS & SS Rain \\
\hline K. Pushkar & $0.96^{* *}$ & $0.86^{* *}$ & -0.08 & $-0.80^{*}$ & -0.51 & $-0.12-0.16$ \\
K. Bahar & $0.97^{* *}$ & $0.91^{* *}$ & 0.09 & -0.68 & -0.40 & $-0.13-0.17$ \\
K. Pukhraj & $0.89^{* *}$ & $0.83^{*}$ & -0.13 & $-0.72^{*}$ & -0.49 & -0.280 .03 \\
K. Badshah & $0.97 * *$ & $0.93^{* *}$ & 0.06 & $-0.68^{*}$ & -0.38 & $-0.15-0.20$ \\
K. Khyati & $0.91^{* *}$ & $0.80^{*}$ & -0.17 & $-0.76^{*}$ & -0.53 & $-0.21-0.02$ \\
K. Surya & $0.94^{* *}$ & $0.86^{* *}$ & -0.10 & $-0.72^{*}$ & -0.50 & $-0.23-0.05$ \\
K. Sadabahar & $0.94^{* *}$ & $0.93^{* *}$ & -0.06 & -0.65 & -0.40 & $-0.31-0.01$ \\
\hline
\end{tabular}

* Correlation is significant at the 0.05 level, ** Correlation is significant at the 0.01 level

agro meteorological observatory of Department of Agricultural Meteorology, C.C.S.H.A.U, Hisar. Correlation and multiple regression analysis were done to work out the relationship among $B$. tabaci population and weather variables. Regression analysis was performed by taking $B$. tabaci population as dependent variable and weather parameters as independent variables.

\section{RESULTS AND DISCUSSION}

\section{Seasonal abundance of whitefly (Bemisia tabaci) population}

Table 1 reveals that $B$. tabaci attacked all the seven potato varieties viz., K. Pushkar, K. Bahar, K. Pukhraj, K. Badshah, K. Khyati, K. Surya and K. Sadabahar. All the seven varieties tested showed that $B$. tabaci population varied from 24 to 85 white flies per plant in different varieties in last week of October in the pooled year (average of 2012 and 2013) when the average maximum temperature was 30.3 ${ }^{\circ} \mathrm{C}$ and minimum temperature was $13.6^{\circ} \mathrm{C}$. The population of B. tabaci decreased gradually with the fall in maximum and minimum temperature thus, in $2^{\text {nd }}$ fortnight of December, there were few B. tabaci present in the crop. In all the varieties $31^{\text {st }}$ October was found to be the actual date of appearance $B$. tabaci population and it is the only date where the peak population of $B$. tabaci was observed.

The per cent incidence of PALCVD on different potato cultivars show that population of $B$. tabaci was directly proportional to potato apical leaf curl virus disease as K. Khyati, which was having maximum number of whitefly (85) in initial tuber initiation stages of the crop growth, had more disease incidence (90\%) and lesser in K. Pukhraj and K. Sadabahar (55\%). Here, it is to be mentioned that although K. Bahar on $31{ }^{\text {st }}$ October had low whitefly population (24 2.5 ) which decreased gradually like the other varieties but reduction in number of $B$. tabaci was at a faster rate in comparison to other varieties. No visible symptoms of the PALCVD appeared on K. Bahar throughout the crop growth. Varietal response to potato apical leaf curl virus is due to differential support to the $B$. tabaci population by these varieties and hence there exist direct relationship betwwen the B. tabaci population and incidence of PALCVD.

\section{Correlation and regressions}

The correlation coefficient of B. tabaci population with different weather variables showed that Tmax and Tmin were significantly and positively correlated with $B$. tabaci population in all the varieties at 5 per cent level (Table 2). Evening relative humidity ( $\mathrm{RHe}$ ) has significant but negative correlation with $B$. tabaci population. RHm WS, SS and rainfall had no significant correlation with $B$. tabaci population.

The multiple regression equation developed with pooled data over year and variety is given below:

$\mathrm{Y}=-128.95+8.20 \mathrm{Tmax}-2.87 \mathrm{Tmin}-1.36 \mathrm{RHe}-4.83 \mathrm{WS}$

$\mathrm{R}^{2}=0.57$

where $\mathrm{Y}$ is denoted for whitefly population.

From the equation, it can be revealed that the weather parameter(Tmax, Tmin, RHe and WS) all together, contribute 57 per cent variation in the population of $B$. tabaci in potato.

\section{CONCLUSION}

It can be concluded that the results indicated that the appearance and buildup of whitefly vector for PALCVD were influenced by varieties, crop seasons, and weather. On the basis of regression analysis for whitefly population (vector) directly proportional to potato apical leaf curl virus disease on pooled data showed that Tmax, Tmin, RHe, and WS were the main contributing weather variables which could explain the vector populations by 57 per cent. 


\section{ACKNOWLEDMENTS}

The authors would like to express their sincere thanks to Head, Department of Plant Pathology and Dr. K.S. Baswana, Head, Department of Vegetable Sciences, C.C.S. Haryana Agricultural University, Hisar for providing facilities to conduct studies. The help rendered by Dr. Naresh Mehta, Associate Dean cum Professor, C.O.A, Dr. Ramniwas, and Dr. Anil Kumar, Department of Agricultural Meteorology C.C.S.H.A.U, Hisar and Pradeep Kumar Dalal (PhD Research Scholar, Department of Entomology).

\section{REFRENCES}

Anonymous, (2013). Directorate of Economics and statistics, during 2012-13. Ministry of Agriculture,Potato in India, Govt. of India FAOSTAT at 3. FAO. Org.

Bashir, M.H., Afzal, M., Sabir, M.A. and Raza,A.B.M. (2001). Relationship between sucking insect-pests and physicmorphic plant characters towards resistant/ susceptibility in some new genotypes of cotton. Pak. Entomol.,23(1-2): 75-78.
Bhatnagar, A. (2007). Incidence and succession of thrips, leafhopper and whitefly in combination of planting dates and potato varieties. Ann. Pl. Protec. Sci., 15: 101105.

Garg, I.D., Kumar, S., Khurana, S.M.P. and Lakra, B.S. (2001). Association of geminivirus with potato apical leaf curl in India and its immuno-electron microscopic detection. J.Indian Potato Assoc., 28(2-4): 227-232.

Lakra, B.S. (2002). Leaf-curl: A threat to potato crop in Haryana. J.Mycol.Pl.Pathol., 32:367.

Lakra, B.S. (2010). Degeneration of potato cultivars due to potato apical leaf-curl virus disease under Hisar ecological conditions. J. Mycol. Pl. Pathol., 37(3-4): 164-166.

Mckinney, H.H. (1923). Anew system of grading plant diseases. J.Agric. Res., 26: 195-218.

Traboulsi. (1995). "Bemisia tabaci: a report on the pest status with particular refrence to the near east". FAO Plant Protection Bull., 42:33-35. 